\title{
The Synergetic Impact of AI, IoT, and 5G on Information Literacy and Education
}

\author{
Mieczysław Muraszkiewicz \\ ORCID 0000-0002-7885-1476 \\ Faculty of Economics and Informatics in Vilnius, Lithuania \\ Branch of the University of Bialystok
}

\begin{abstract}
Purpose/Thesis: The purpose of the study is to argue, explain and justify that a troika of AI (Artificial Intelligence), IoT (Internet of Things), and 5G broadband cooperating with each other has the transformative power that can provide a synergetic impact on the information literacy and education. The troika can provide new methodologies and tools that will unleash and boost the spirit of innovation and trigger energy, passion, and creativity resulting in developing better education ecosystems.

Approach/Methods: The method adopted in the study is twofold, namely: (i) it presents and examines the features of AI, IoT, and 5G and the way they can cooperate with each other in order to develop new education models and patterns, and then analyses the issue of e-literacy by breaking it apart into e-skills, information literacy, and media literacy; (ii) it shows how AI, IoT, and 5G can support information literacy and education.

Results and conclusions: The outcome of the research is the presentation and examination of AI, IoT, and $5 \mathrm{G}$ collaborating with each other towards transforming education models and processes. It concludes that the AI, IoT, and 5G troika has a great potential to boost teaching and learning, and to inspire and support the development of new generation educational ecosystems. However, in the digital age information literacy and education is too serious a matter to be left solely to educators and ICT technologists. Learners, students, and concerned citizens need to be involved in the transformation processes.

Originality/Value: The originality and value of the research is to prove that while working together $\mathrm{AI}, \mathrm{IoT}$, and $5 \mathrm{G}$ can provide a significant support for transforming the present education patterns, in particular regarding the information literacy that is a condition sine qua non of effective education in the digital era. This can help scholars and education communities to unleash innovativeness aimed at developing new generations of educational ecosystems, and thereby make learning and teaching processes more efficient and available to significantly larger audiences.
\end{abstract}

\section{Keywords}

Artificial intelligence. Internet of Things. 5G. Information literacy. Education.

Received: 30 November 2019. Reviewed: 5 December 2019. Accepted: 9 December 2019.

\section{Introduction}

This paper addresses the issue of information literacy and education in the age of advanced information and communication technologies. We can see how students, engineers, humanists, entrepreneurs, managers and decision makers, and teachers are constrained in performing their jobs and hobbies because their understanding, skills and knowledge about 
the mechanisms and potential of the Internet and resources that are available via the Internet are limited and locked in daily routines. These persons lack not only more advanced e-skills but also their information literacy is not up to the tasks they want to perform. The consequences of this fact can be widely seen around us in the form of missed opportunities, suboptimal or false decisions, poor efficiency or even wasted resources and funds, hazards, people's disappointments and frustrations, and so on and so forth. It is thus of paramount importance to devise and implement mechanisms of e-literacy capacity building, including as clearly pointed out in (Bruck, 2008): "The sustainability of skills and abilities as well as the transfer of such skills and abilities from training environments to real-life situations in projects and work". This is why this paper was written.

It is believed that today a broadband is, mutatis mutandis, as important as the electricity was in the 19th and 20th century. In a nutshell, through broadband we not only get swift access to vast information resources and services of the Internet but also a comfort of real-time online communications with other people no matter the distance. The latter is psychologically a crucial condition of satisfactory interaction and building and maintaining social relationships, so important for humans and their development. Along with Information and Communication Technologies (ICT) broadband is a horizontal impact technology going across public and private facets of life. It is also an irreplaceable means for providing contemporary and future education, whatever its type and form, with tools to develop information and/or media literacy either on one's own or following an established scheme within a school, an institution, or a company.

In order to understand and stand up to all incoming backwaters, crises, downturns, turning and tipping points, and challenges, the world is in desperate need of talents, creativity and a number of well-educated and aware people counted in billions rather than millions. The existing education infrastructure by no means can offer a workable solution of this issue, which becomes critical to the whole mankind. Without a risk of being exaggerative one can hold that the survival of the human species is at stake.

Educational systems throughout the world have usually been behind the curve of "real life". This is probably the chief reason why they have been subject to permanent reforms that turn out of little or no use at all, for they have attempted to improve the system that is already inherently broken and irrelevant to the constantly progressing and transforming world. Most of the present education system was conceived and devised as a response to the emerging industrialization of the 19th and the beginning of the 20th centuries that needed millions of unified and disciplined workers to provide crude labor force for mass scale production. Incidentally, let us note that this system itself was very much industrialized and worked like an unconscious machine. The school was supposed to prepare prefabricated unreflective, disciplined workers, a simple labor force, which could be easily integrated with the world of factories and offices. Later on, throughout the second part of the 20th century, the education system tilted towards the model of the fast food, as mentioned by Sir Ken Robinson (Robinson, 2014). Indeed, a soaring yet not sophisticated sectors of administration and a growing service sector needed merely a few types of standardized clerks whose profiles and skills were expected to be the same or very similar worldwide. The result: "We are educating people out of their creativity" notes Sir Ken Robinson.

It is noted that the period of mass and massive unified industrial production retreats to the past. The present time is governed by specialized labor-force, mobile experts and 
consultants, sophisticated machines and factory robots, ICT communication facilities, refined management techniques, and by unique know-how and knowledge. The focus of modern capitalism has shifted from the production of material goods such as vehicles, TV and game sets, or computers and smartphones towards symbolic, intangible goods such as intellectual property rights, entertainment, experiences, health, and also education that becomes on the one hand a commodity offered in a staggering variety of forms on the educational marketplace, and on the other hand, a grass-root product made available without a fee or at a price depending on who offers it and for whom it is offered.

The old economic and social order has passed into history; yet, the education system based on the paradigm of "chalk and talk" overpopulated classes still remains in place and, which is even worse, it is firmly rooted in people's (parents') minds who at times cannot contemplate that their children might learn differently than they did. Every effort has to be made to close this chapter of the "fast food" standardized education, and to move on to customized education patterns tailored for individual students by taking into account their talents, predispositions and preferences, and above all giving them rights to shaping their learning paths by themselves.

The major lesson one can draw from all these failed reforming efforts is that the dogmas of educational theories and practices of the past are no longer valid to the present, and a fortiori to the future ways for educating people. In particular, the evolutionary approach applied to the present system for mending it is not the rightest strategy; rather new ideas and concepts need to be worked out, tested, and implemented. The world we live in is new, therefore, we have to think and act innovatively, identify and abandon routines. Horace's principle sapere aude (dare to be wise) adopted by Immanuel Kant to depict the essence of the Enlightenment has to be applied to the redesign of our educational systems. Needless to argue that it is a daunting task indeed, as we live under the unanimous tyranny of common sense, which in the guise of reason and unfeasibility of the "it can't be done under our current system" attitude truly hampers productive change towards recovery and renewal of the system.

This paper strives to enlighten the reader that artificial intelligence, the Internet of Things, and the $5 \mathrm{G}$ broadband access to the digital universe and media, if made available to large parts of populations and above all to the youth, can unleash and boost the spirit of innovation and trigger energy and passion, and creativity aimed at developing and establishing educational ecosystems of a new generation. A condition sine qua non to achieve it is to include advanced e-literacy in schools' curricula. In parallel, it is of paramount importance to significantly reduce e-exclusion by providing true broadband access and e-literacy to as many citizens as possible, whatever their age, gender, profession, ethnicity, etc.

The structure of the paper is as follows. In the next section we shall explain the notions of $5 \mathrm{G}$ broadband, the Internet of Things, and artificial intelligence, and then in section 3 we discuss the matter of e-literacy that includes e-skills, information literacy, and media literacy. In section 4 we will show how $5 \mathrm{G}$ broadband, e-literacy, and the Internet of Things can go hand in hand towards new kinds of educational ecosystems. 


\section{The synergy of ICT boosters (5G, IoT, and AI)}

The Internet and mobile communication revolutions that we have been witnessing for four decades, or so, have been influencing human life to the extent comparable or perhaps even greater than previous revolutions such as the agricultural or industrial ones. While the latter dealt with material entities, the present revolution deals with such intangible yet significant entities as data, information, and knowledge. This difference is of particular importance for it touches upon the very essence of humanity, which is its self-awareness relative to the experience and knowledge acquired over millennia. These days we can see the acceleration of the information and communications technology revolution whose driving forces are the advancements in artificial intelligence (along with big data and machine learning), the Internet of Things, and 5G technologies. This troika is the underpinning of what is called smart cities, which concept defines the future of humans' habitats and thereby the future of human civilization. The troika has also the potential to considerably re-engineer the education systems at all levels and types of teaching and learning, which is also the pivotal pillar of the human future. Further on, we shall elaborate on these forces and the synergy they can unleash to boost information literacy, media literacy and education.

\section{1. $5 G$ broadband}

Broadband access, or simply broadband, is the term that one can find on governments and multinational organizations agendas as a prerequisite of modernization, development, growth, and democratization. Simply speaking this term means speed-access or, in other words, a high data rate connection to a mobile telephony operator or an Internet service provider. Metaphorically, broadband is a gateway to the universe of the Internet with its immense information resources and cornucopia of services, available thanks to the wide bandwidth data transmission that transports multiple signals and traffic types. In the year of 2017 the U.S. Federal Communications Commission (FCC) set up the broadband benchmark by considering the presence of either fixed (at $25 \mathrm{Mbps} / 3 \mathrm{Mbps}$ ) or mobile (at $10 \mathrm{Mbps} / 1 \mathrm{Mbps}$ ) broadband as an indication that an area has adequate broadband service (CRS, 2018). Since then the thresholds for defining the broadband speed have got constantly greater. According to the Speedtest Global Index (Speedtest, October 2019), the world fixed broadband average speed accounted for 54.46 Mbps (download-70.68 Mbps, upload-38.23 Mbps). Incidentally, Poland reached the level of $85.97 \mathrm{Mbps}$ (32 position in the ranking), and the leader, Singapore, 194.09 Mbps. For the global mobile broadband, the Index informs that the average speed was 20.81 Mbps (download-30.02 Mbps, upload-11.59 Mbps). South Korea was the leader of the ranking with the average speed of 112.77 (Poland's average speed was $34.94 \mathrm{Mbps} ; 46$ place in the ranking). In terms of latency, which is any kind of delay that occurs in data communication through a network and therefore is an important parameter of transmissions, the report (Boyland, 2019) reads that the users' averaged latency experience scores under 40 milliseconds in 13 out of 87 investigated countries and that none of them broke the barrier of $30 \mathrm{~ms}$.

Countries make efforts to provide broadband access to their citizens at an affordable price as they consider it a vital leverage of economic and societal development and better off, in particular to improve their education systems. A true broadband, meaning at least 
$50 \mathrm{Mbps}$ for the fixed connection and $20 \mathrm{Mbps}$ for the mobile one is now changing the way people access and use the Internet and services available on the web. The Internet becomes in a broad sense a platform where access to and use of the media get democratized, and communications between people is boosted. In this context one needs to mention the fast dissemination of cloud computing; this paradigm of computation consists on shifting data, software, and sophisticated hardware along with business applications from one's working place (a company or a home place) to external service providers whose physical location and configuration of processing equipment are abstracted from the users. More on the principles of cloud computing, its history, potential, progress, promise, and implications, including risks one can read in (Jackson \& Goessling, 2018; Sosinsky, 2011).

The only constant in the realm of mobile communications is change. Within the space of some 15 years we have witnessed a few significant generations, which are 2G, 2.5G (GPRS), 2.75 (EDGE), 3G, 4G (LTE), and now 5G. The present jump from 4G to 5G is particularly spectacular. While an average LTE transmission speed is around $21 \mathrm{Mbps}$, which allows one for comfortable uncut music streaming and smooth web surfing, the $5 \mathrm{G}$ connection is up to one thousand times faster and can reach $10 \mathrm{Gbps}$ or more, which, for example, makes it possible to download a full high definition movie in about 10 seconds. The transmission speed increase is accompanied by a delay time reduction as the connection latency shrinks from 50 milliseconds to just one or two milliseconds, and by the almost boundless increase in the number of various devices (smartphones, tablets, laptops, etc.) that can be connected simultaneously. These tremendous performance parameters make the $5 \mathrm{G}$ technologies a true game changer in many domains of our lives and work.

While discussing the prospect of $5 \mathrm{G}$ and its general impact one important thing has to be noted and emphasized, namely a very high cost to build 5G networks. These new generation networks require a lot of investments in new infrastructure and a vast amount of organizational work and logistics. This is one of the reasons why some so-far competing network operators have been looking for cooperation and sharing costs, sometimes under the umbrella of the state, which is the case of Poland. Another point is that it is obvious for the operators that the consumer smartphone use case alone cannot justify such huge expenditures. The operators have to investigate and explore new territories, meaning services, applications, and security, as well as, new marketing strategies in order to pay off the investments. Towards this end, the signpost is the digitalization of widely understood existing commercial and non-commercial services and applications. Now, such terms as digital economy, digital culture, digital health care, digital education, digital agriculture, digital entertainment, smart cities, autonomous vehicles, industry 4.0 and much more become a reality. It is expected that as a result of its pervasiveness, high data rates, low latency, energy savings, reduction of operation costs, and higher network capacity $5 \mathrm{G}$ will deeply shape and transform business models, the modus operandi of administration, health care, military sector, police, and other agencies, as well as, private lifestyles. The new and upgraded augmented reality and virtual reality applications based on $5 \mathrm{G}$ will gain serious attention and interest of such important sectors of economy as tourism, entertainment, health service, and education to mention a few. Virtual trips will become commonplace, multiplayer mobile gaming will escalate, remote diagnosis and health assessments will be available to ordinary citizens, and distance learning will get easier and more popular, and become a support to the life long learning programs. In author's opinion, it is no exaggeration 
to say that $5 \mathrm{G}$ technologies is a genuine game changer that will transform the landscape of the digital universe and will be the glue that will join and hold artificial intelligence and the Internet of Things together. The synergy of artificial intelligence, the Internet of Things and 5G combined will unleash new energy and opportunities throughout societies.

\subsection{The Internet of Things}

A tremendous performance of the $5 \mathrm{G}$ technologies makes $5 \mathrm{G}$ the most instrumental tool for designing and developing solutions based on the Internet of Things (IoT) paradigm, which itself is another revolutionary concept changing the way people will live and work. The Internet of Things is the term attributed to Kevin Ashton and goes back to the year of 1999 (Ashton, 2009) when Ashton proposed the use of RFID tags to improve the control of supply chains. Since the outset of the present century IoT has become a hot topic of interest among business communities, manufacturers, and municipal authorities interested in the concept of smart cities. In a broad sense IoT includes all devices that are interconnected on the closed private Internet connections and can communicate ("talk") to each other and are able to collect data by means of various types of sensors from the environment they are immersed in. The IoT components can analyze the acquired data and trigger the actions of actuators or to inform people in order to help them make decisions and to control processes they are involved in. One can look at the IoT structure as a responsive framework, which interfaces the physical world with computer systems and by means of them with their users. Sometimes IoT is also dubbed the Internet of Everything in order to emphasize the fact that interconnected are not only the things such as sensors, computers, robots, and home appliances (think of the fridge that tells you when you run out milk and orders it online) but also large systems and even people through their personal digital devices such as smartphones or health wearables that track data about the human body. Already today one can come across the IoT solutions in many domains among which are medicine, manufacturing, in particular industry 4.0, smart buildings/homes and smart cities, smart grids (energy), transportation, connected cars, inventories, supply chains, wholesale and retail trade, agriculture and farming, to mention a few only. Gartner analysts predict that 5.81 billion enterprise and automotive IoT endpoints will be in use in the year of 2020 (Gartner, 2019). Table 1 provides a breakdown of the endpoints across the market segments over the period of 2018-2020.

IoT as any other ICT system faces divers challenges, of which the most difficult to address are security, data protection, and ethics. The number of interconnected devices of various kinds, large amounts of data stored, shared and transferred, heterogeneous groups of users, which altogether constitute an IoT network can encourage hackers' attacks and cause many security concerns about breaching the network firewalls. With the data protection and security issue is related the problem of privacy when IoT includes devices that collect personal data, for instance, such as health information gathered by the aforementioned health wearables. Another challenge is the need of standardization that is difficult to address because of wide-ranging types of devises and processes running on the IoT installations. 
Tab. 1. IoT Endpoint Market by Segment, Worldwide, 2018-2020

Source: Gartner, 2019

\begin{tabular}{|l|c|c|c|}
\hline \multirow{2}{*}{\multicolumn{1}{|c|}{ Segment }} & 2018 & 2019 & 2020 \\
\cline { 2 - 4 } & \multicolumn{3}{|c|}{ billions of units } \\
\hline Utilities & 0.98 & 1.17 & 1.37 \\
\hline Physical Security & 0.83 & 0.95 & 1.09 \\
\hline Government & 0.4 & 0.53 & 0.7 \\
\hline Manufacturing \& Natural Resources & 0.33 & 0.4 & 0.49 \\
\hline Automotive & 0.27 & 0.36 & 0.47 \\
\hline Building Automation & 0.23 & 0.31 & 0.44 \\
\hline Retail \& Wholesale Trade & 0.29 & 0.36 & 0.44 \\
\hline Information & 0.37 & 0.37 & 0.37 \\
\hline Healthcare Providers & 0.21 & 0.28 & 0.36 \\
\hline Transportation & 0.06 & 0.07 & 0.08 \\
\hline Total & 3.96 & 4.81 & 5.81 \\
\hline
\end{tabular}

\subsection{Artificial intelligence}

John McCarthy who is acknowledged as a father of artificial intelligence (AI) considered intelligence

the computational part of the ability to achieve goals in the world. Varying kinds and degrees of intelligence occur in people, many animals and some machines (McCarthy, 2007).

For him intelligence had something to do with computations. It is thus not surprising that when asked about the definition of artificial intelligence he said:

It is the science and engineering of making intelligent machines, especially intelligent computer programs. It is related to the similar task of using computers to understand human intelligence, but AI does not have to confine itself to methods that are biologically observable (McCarthy, 2007).

A somewhat witty definition of AI goes as follows: it is

the study of how to make computers do things at which, at the moment, people are better (Reich \& Knight, 1991).

There have been many definitions of AI, which reflects the fact that different researchers have approached and thought of AI differently. These discrepancies were visible in the course of the AI development since its birthday in the mid 1950s of the previous century. It turned out that not all roads of the AI research led to Rome. The history of AI has to its account genuine achievements and enthusiasm, but also misplaced optimism and defeats, resulting in disappointments and loss of confidence in its potential. At present, AI is in a full swing thanks to the achievements in deep neural networks, machine learning, and 
big data analytics. A conventional approach to AI, inspired by the founders of artificial intelligence and sometimes referred to as GOFAI (Good Old-Fashioned Artificial Intelligence), was based on the symbolic representations of the problems to be solved, mainly by means of logic. It was a classic top-down approach that assumed that intelligence had to do with the manipulations of symbols. However, the successes of GOFAI have been limited to relatively small range of problems, perhaps with the exception of the so called expert systems based on production rules. An alternative paradigm to GOFAI is to tackle problems organically and let the AI programs learn on the job and excel their performance through a large number of iterations using big datasets. New machine learning algorithms and big data analytics turned out a relevant approach to transfer AI from academic labs to real life application domains.

It seems that now we are witnessing a breakthrough in the AI development and capabilities. Businesses, industries, public administrations and many others cut in line to hire data science specialists in order to add value to their on-going and planned projects by inserting AI components. The list of AI applications is really long these days. It goes horizontally through practically all domains of work and life. AI seems to be one of the most powerful technologies ever, and its dynamics is remarkably growing. Irving J. Good, a collaborator of Alan Turing, already in 1966 noted:

Let an ultra-intelligent machine be defined as a machine that can far surpass all the intellectual activities of any man however clever. Since the design of machines is one of these intellectual activities, an ultra-intelligent machine could design even better machines; there would then unquestionably be an intelligence explosion and the intelligence of man would be left far behind. Thus the first ultra-intelligent machine is the last invention that man need ever make (Good 1965).

In this prediction Good showed two sides of the same coin: on the one side AI can deliver intelligent solutions that will contribute to the betterment of human condition, but on the other side it may become a challenge that will threat the human existence. Prof. Stephen Hawking warned in the interview given for the BBC on November 2nd, 2014:

Efforts to create thinking machines pose a threat to our very existence. It would take off on its own, and re-design itself at an ever-increasing rate. Humans, who are limited by slow biological evolution, couldn't compete, and would be superseded (Cellan-Jones, 2014).

Hopefully this dark prediction will not become true.

The AI potential mainly lies in its ability to carry out reasoning and acquiring new knowledge or in other words in learning, and thereby to adapt to new circumstances. AI offers such techniques as classification, clusterization, association rules, text summarization, language identification, pattern recognition, prediction, speech recognition and speech synthesis, heuristics, deep learning, big data analysis, and natural language processing. These are the chief techniques that make AI a suitable methodology and instrument to significantly boost teaching and learning processes of various kinds. AI can bring up education to the next level by adding value through customization, namely by student/teacher profiling through machine learning techniques, and by setting personal learning portfolios using learning analytics. 


\section{Information literacy}

New models of teaching and learning are to a large extent based on making use of ICT and the Internet, and thereby assume that teachers and students are e-literate. In a nutshell, e-literacy (sometimes referred to as digital literacy) means that an individual has the willingness, knowledge, and skills to use stationary and mobile information and communication technologies, in particular the Internet, to support her/his professional and/ or other activities. We repackage the term e-literacy into three bunches, namely e-skills, information literacy, and media literacy. By e-skills we understand a set of capabilities that allow one to smoothly, fluently, confidently and critically make use of the appropriate ICT tools, as well as the services and resources belonging to the digital universe of the Internet. Fluent usage of the digital arsenal, be it ICT devices, operating systems, and/or applications is a necessary condition to exploit opportunities offered by ICT, in particular by the Internet. It is worth noting that the process of acquiring e-skills is a multi-level task. For most of us just basic skills are sufficient to cope with and benefit from our laptops, smartphones and the Internet. However, more advance use of the digital artifacts requires specialized training and efforts. Fortunately, a number of training and learning facilities are widely available, and basic courses of ICT have been introduced to curricula of most schools. While skipping over this topic we shall now elaborate more on the two remaining components of e-literacy, i.e. information literacy and media literacy.

An intuitive straightforward understanding of the term information literacy is that this is a set of one's skills and knowledge that allows one to collect, filter, evaluate and organize information and knowledge to address one's information needs in the best possible manner, which includes further processing of the acquired information. Although relatively old yet still very apt, is the definition provided by The American Library Association, which reads:

To be information literate, a person must be able to recognize when information is needed and have the ability to locate, evaluate, and use effectively the needed information (ALA, 1989).

An extension of this definition was given by the Association of College and Research Libraries (ACRL) that added the following words:

Understanding the economic, legal, and social issues surrounding the use of information, and access and use information ethically and legally (ACRL, 2006).

In the year of 2016 ACRL published a broad definition of information literacy that reads:

Information literacy is a set of integrated abilities encompassing the reflective discovery of information, the understanding of how information is produced and valued, and the use of information in creating new knowledge and participating ethically in communities of learning (ACRL, 2016).

This article subscribes to this definition for it reflects not only the process of acquiring information but also it emphasizes the act of creating new knowledge. And this is the place where the synergy of the AI, IoT, $5 \mathrm{G}$ troika can be at work. Table 2 shows how the troika can support the operations and issues characteristic for information literacy. 
Tab. 2. Impact of Ai, IoT, and 5G on information literacy

\begin{tabular}{|l|c|c|c|}
\hline \multicolumn{1}{|c|}{ Topics related to information literacy } & AI & IoT & 5G \\
\hline Identifying and/or defining information needs & $\mathrm{x}$ & $\mathrm{x}$ & $\mathrm{x}$ \\
\hline Selection of information resources & $\mathrm{x}$ & & $\mathrm{x}$ \\
\hline Information retrieval strategies & $\mathrm{x}$ & $\mathrm{x}$ & $\mathrm{x}$ \\
\hline Selection and acquisition of information & $\mathrm{x}$ & & \\
\hline Content analysis of acquired information & $\mathrm{x}$ & & \\
\hline Evaluation of acquired information & $\mathrm{x}$ & & \\
\hline Aggregation/creation of content & $\mathrm{x}$ & $\mathrm{x}$ & $\mathrm{x}$ \\
\hline Use of acquired information & $\mathrm{x}$ & $\mathrm{x}$ & $\mathrm{x}$ \\
\hline Making available (dissemination/sharing) of acquired information & $\mathrm{x}$ & $\mathrm{x}$ & $\mathrm{x}$ \\
\hline Development of media competences & $\mathrm{x}$ & $\mathrm{x}$ & $\mathrm{x}$ \\
\hline Development of communication skills & $\mathrm{x}$ & $\mathrm{x}$ & $\mathrm{x}$ \\
\hline Development of ICT competences & & \\
\hline
\end{tabular}

The " $x$ " signs lying at the intersection of columns and rows in Table 2 indicate that respective issues of information literacy (rows) are influenced by one or more technologies of the troika (columns). Given the factual material presented in section 2 it is left to the readers to expand and elaborate on the nature and scope of this influence.

Let us now take a closer look at the issue of media literacy. The US-based National Association for Media Literacy Education (NAMLE) defines media literacy as

the ability to access, analyze, evaluate, create, and act using all forms of communication. In its simplest terms, media literacy builds upon the foundation of traditional literacy and offers new forms of reading and writing. Media literacy empowers people to be critical thinkers and makers, effective communicators and active citizens (NAMLE, 2019).

It should be noted that this definition includes an act of creation of content, authoring, whereas the notion of information literacy is rather focused on locating, retrieving, and using content only. Ofcom, an independent regulator and competition authority for the UK communications industry, which regulates the TV and radio sectors, fixed line telecoms and mobiles, and the airwaves over which wireless devices operate gives the following definition of media literacy: it is

the ability to use, understand and create media and communications in a variety of contexts ... Media literacy enables people to have the skills, knowledge and understanding to make full use of the opportunities presented by both traditional and new communications services. Media literacy also helps people to manage content and communications, and protect themselves and their families from the potential risks associated with using these services (Ofcom, 2019a).

Noteworthy, the Ofcom definition and description of media literacy goes beyond the one by NAMLE, as it mentions a timely topic of risks related to fake news, hate speech, and other acts of misusing media. 
In the year of 2019, Ofcom published a report based on around 5.000 interviews with adults aged 16 years and elder (Ofcom, 2019b). Here, are some of the most relevant results within the report.

- Mobile phones have become an integral part of everyday life - 96\% of adults use mobile phones. The reliance on mobile phones grows, half of adults consider their mobile phone the device they would miss the most if it were taken away.

- The use of computers to go online is falling from $62 \%$ in 2017 to $58 \%$ in 2018 , whereas the use of smartphones to go online increases from $8 \%$ in 2017 to $11 \%$ in 2018.

- Video on demand and streamed content becomes a main part of adults' viewing habits. Incidents of watching on-demand or streaming content grew from $55 \%$ in 2017 to $60 \%$ in 2018 .

- The users of social media in 2018 are less likely than in 2017 to visit the sites where they could see the views with which they disagree. Facebook is still the most popular service; however, it is worth noting that the proportion of Internet users who considered Facebook their main site dropped from $70 \%$ in 2017 to $58 \%$ in 2018.

- It is more likely to come across hateful content online - 53\% up in 2018, from $47 \%$ in 2017). Interestingly, the most Internet users didn't do anything about it.

- Internet users' awareness of manners in which institutions and companies can gather personal information online looks as follows: 7 in 10 users are aware of cookies being used to collect information; 6 in 10 are aware of information being collected through social media; 6 in 10 are aware of information being collected through registrations; and 5 in 10 are aware of information being collected through smartphone apps; 3 in 10 do not make "media-literate" checks before entering their personal data online.

- Awareness of personalized advertising has practically remained at the same level since $2017-6$ in 10 users are aware that other users might see different adverts to the ones they see.

The picture that emerges from the Ofcom reports (from the one we referred to above and the ones that are available on the official Ofcom website) shows that the level of media literacy observed on the Internet, including its mobile part, is growing; yet the pace is not dramatic. The users interested in carrying out their own analysis of media literacy in UK can use a media tracker, which is the utility that provides rich and comprehensive information on UK adults' attitudes and opinions on the use of media (MT, 2019). Guessing that the UK case is to a large extent representative for economically and socially advanced countries it would nevertheless be interesting to compare it with the situations in other countries, this however remains beyond the scope of this paper.

\section{AI, IoT, and 5G impact on education}

Classic education is based on the idea of linearity. The narratives taking place at most of the schools are linear, single track, and slow. The progress of skills and knowledge absorption is gradual and lengthy. Conformity is another feature of the present education model. The instruction is mainly based on one-to-many model in which a teacher speaks to a class. But life and our perception apparatus are not linear; they are parallel and organic. We need to change the metaphor of education from linearity, compliance, single source of information, 
and broadcasting to parallelism, creative freedom, broad variety of knowledge sources, dense interaction, and frequent hands-on. We have to abandon the education style that produces clones; we need different individuals featuring critical thinking, moral autonomy and integrity. New teaching and learning models are about customizing and personalizing education to the circumstances of students. People engaged in learning usually want to develop their own solutions based on external support taking into account their internal predispositions, talents, and predicaments. In parallel with learning and teaching in classes at schools and universities the cyberspace offers three generically new components that can be integrated with classic formal and informal learning models, learning habits, patterns and processes, which are:

- e-learning (Jacobfeuerborn, 2010), and AI-injected learning (Montebello, 2018);

- virtual learning communities (Palloff \& Pratt, 2009; Stevenson \& Bauer, eds., 2019);

- crowdsourcing (Cummings, 2019; Surowiecki, 2005).

This is where one introduces $5 \mathrm{G}$ broadband, IoT, and AI without which these three new education means and models could not unfold their wings and became a valuable component of education practice and contribute to making available educational opportunities to the general public, meaning to democratize education. These modi operandi particularly apply for teaching, training, and promoting e-literacy, including information literacy.

Democratization of education understood as easy, equal and universal access to education resources and opportunities has been a long-lasting dream of many generations that considered education a way to emancipation, social participation, stability, and prosperity. Putting apart the reason that the issue of democratizing education is to a significant extent of a political matter, the major obstacle for distributing educational opportunities has been lack of technology and/or high costs to make learning and teaching facilities pervasive, ubiquitous, and reachable at a minimal cost or for free. Now these barriers become of less importance and we can start thinking of elaborating a new education paradigms and culture for all domains: schools, academia, business, administration, and self-learning, and to make education, toutes proportions gardées, an utility that is available to large populations. This idea was expressed in (Downes, 2007) as follows

The idea is that learning is not based on objects and contents that are stored, as though in a library. Rather, the idea is that learning is like a utility - like water or electricity - that flows in a network or a grip that we tap into when we want (slides 49-50).

$\mathrm{AI}$, IoT and $5 \mathrm{G}$ enhanced by big data and cloud computing can bring on the spirit of innovation and unleash creativity and energy in the field of education; they can help transform it into a utility. The Internet is widely and increasingly consulted for self-directed learning, used as a library, and for offers in education and training. The important role of broadband for education was already expressed in The National Broadband Plan prepared by the Federal Communications Commission of the U.S. that reads:

Broadband can be an important tool to help educators, parents and students meet major challenges in education. The country's economic welfare and long-term success depend on improving learning for all students, and broadband-enabled solutions hold tremendous promise to help reverse patterns of low achievement (FCC, 2010, 226).

This opinion remains unchanged. We add to this opinion that providing broadband to the homes, institutions, and organizations is not enough, and in a sense it is an easier task to overcome e-exclusion. The more strenuous task is the development of e-literacy whose 
vital part is information literacy in large heterogeneous populations, i.e. to provide them with actual skills necessary to make use of the Internet resources and to redesign the whole education system.

Tab. 3. Technologies and tools to boost teaching and learning

\begin{tabular}{|c|c|c|c|c|}
\hline Activity & ICT Technologies \& Tools & AI & IoT & $5 \mathrm{G}$ \\
\hline Lecture & $\begin{array}{l}\text { access to a local repository of educational material; tools } \\
\text { for content/slides presentations; video-conferencing tools } \\
\text { for re-mote lecturing in a class; distance learning, including } \\
\text { e-learning (synchronous, asynchronous); } 2 \mathrm{D} \text { and 3D visuali- } \\
\text { zation packages; virtual whiteboard; video players; access to } \\
\text { the Internet, including the web, and access to repositories of } \\
\text { inspirational educational videos; Internet browsers }\end{array}$ & $\mathrm{x}$ & $\mathrm{x}$ & $\mathrm{X}$ \\
\hline $\begin{array}{l}\text { Seminar } \\
\text { (tutorial) }\end{array}$ & $\begin{array}{l}\text { content/slides presentations and sharing tools; mind maps; } \\
\text { virtual whiteboard; wikis; video-conferencing; blogs; blog } \\
\text { writing tools; automatic content analysis tools; text summa- } \\
\text { rization tools; access to the internet; internet browsers }\end{array}$ & $\mathrm{X}$ & & $\mathrm{x}$ \\
\hline Consultation & $\begin{array}{l}\text { video-conferencing; access to the internet, including the web } \\
\text { communicators; email; blogs; social networking tools }\end{array}$ & & & $\mathrm{X}$ \\
\hline $\begin{array}{l}\text { Research } \\
\text { seminar }\end{array}$ & $\begin{array}{l}\text { tools for content/slides presentations and sharing tools; } \\
\text { mind maps; virtual whiteboard; wikis; communicators; } \\
\text { video-conferencing; access to the interne; internet browsers } \\
\text { along with heuristics; automatic content analysis tools; text } \\
\text { summarization tools; blogs; blog writing tools }\end{array}$ & $\mathrm{x}$ & & $\mathrm{x}$ \\
\hline $\begin{array}{l}\text { Laboratory } \\
\text { and workshop } \\
\text { (practical } \\
\text { classes) }\end{array}$ & $\begin{array}{l}\text { tools for content/slides presentations and sharing tools; mind } \\
\text { maps; virtual whiteboard; access to the Internet; Internet } \\
\text { browsers along with heuristics; augmented and virtual reality } \\
\text { (immersive technologies) tools and environments; on-line tests }\end{array}$ & $\mathrm{x}$ & $\mathrm{x}$ & $\mathrm{X}$ \\
\hline Field work & $\begin{array}{l}\text { wireless and mobile technologies, smart mobile devices, } \\
\text { communicators, video conferencing; social networking tools; } \\
\text { email }\end{array}$ & & $\mathrm{x}$ & $\mathrm{x}$ \\
\hline Simulation & $\begin{array}{l}\text { augmented and virtual reality (feelings and experiences } \\
\text { when immersed in mixed reality environments); awatars; } \\
\text { second life }\end{array}$ & $\mathrm{x}$ & $\mathrm{x}$ & $\mathrm{X}$ \\
\hline $\begin{array}{l}\text { Student } \\
\text { project } \\
\text { (individual and } \\
\text { team work) }\end{array}$ & $\begin{array}{l}\text { mind maps; wikis; social networking tools; communicators; } \\
\text { video-conferencing; automatic content analysis tools; text } \\
\text { summarization tools; blogs; blog writing tools; access to the } \\
\text { Internet; internet browsers; email. }\end{array}$ & $\mathrm{x}$ & $\mathrm{x}$ & $\mathrm{x}$ \\
\hline $\begin{array}{l}\text { Discussions } \\
\text { and debates }\end{array}$ & $\begin{array}{l}\text { communicators; video-conferencing; automatic content } \\
\text { analysis tools; text summarization tools; blogs; blog writing } \\
\text { tools; access to the internet; social networking tools }\end{array}$ & $\mathrm{x}$ & & $\mathrm{x}$ \\
\hline Brain storming & mind maps; brainstorming tools; social networking tools & & & $\mathrm{x}$ \\
\hline
\end{tabular}

In order to reach this objective initiatives and concrete measures have to be undertaken from two sides. On the one hand, technical facilities need to be simpler, ergonomic and 
user friendly, which is mainly the task addressed to designers, developers, engineers and manufacturers and to all those who set up services on the Internet. On the other hand, governments, educational institutions, experts, and non-governmental organizations have to engage in elaborating new education models addressing different levels and kinds of education, and also in providing awareness and training on the use of the AI, IoT, and mobile technologies.

Table 3 specifies an assorted set of forms/activities of teaching and learning and indicates which of them AI, IoT, or $5 \mathrm{G}$ tools or solutions could support.

\section{Final remarks}

This article concludes with two short notes, subject to further pondering. The first one is that within a classic model of education a charismatic, knowledgeable teacher could influence, say, hundreds of students during her/his professional career; now, thanks to the Internet and advanced ICT fixed and mobile facilities supported by AI it can be millions, as it is the case for some online courses offered by highly ranked universities. The second note rephrases a famous adage by Charles de Gaulle on politics and politicians. We can thus say that in the digital age information literacy and education is too serious a matter to be left solely to educators and ICT technologists. Learners, students, and concerned citizens have to be in the loop of this process and be the loop itself.

\section{References}

ALA (1989). Presidential Committee on Information Literacy. Final Report [online]. American Library Association [25.10.2019], http://www.ala.org/ala/mgrps/divs/acrl/publications/whitepapers/ presidential.cfm

ACRL (2006). Information Literacy Standards for Science and Engineering/Technology [online]. Association of College \& Research Libraries [25.10.2019], http://www.ala.org/acrl/standards/ infolitscitech

ACRL (2016). Framework for Information Literacy for Higher Education [online]. Association of College \& Research Libraries [25.10.2019], http://www.ala.org/acrl/standards/ilframework

Ashton, K. (2009). That 'Internet of Things' Thing. RFID Journal [online], May/June, [30.11.2019], http://www.rfidjournal.com/articles/pdf?4986

Boyland, P. (2019). The State of Mobile Network Experience. Benchmarking Mobile on the Eve of the 5G Revolution [online]. Opensignal [30.11.2019], https://www.opensignal.com/sites/opensignal-com/files/data/reports/global/data-2019-05/the_state_of_mobile_experience_may_2019_0.pdf

Broadband (2019). Wikipedia. The Free Encyclopedia [29.11.2019], https://en.wikipedia.org/wiki/ Broadband

Bruck, P. A. (2008). Welcome and Introduction to "Micromedia and Capacity Building". In: P.A. Bruck, M. Lindner (eds.). Microlearning and Capacity Building. Proceedings of the 4th International Microlearning 2008 Conference (1-6). Innsbruck: Innsbruck University Press.

Cellan-Jones, R. (2014). Stephen Hawking warns artificial intelligence could end mankind [online]. BBC. News. Technology [29.11.2019], https://www.bbc.com/news/technology-30290540

CRS (2018). Defining Broadband: Minimum Threshold Speeds and Broadband Policy [online]. Congressional Research Service [21.10.2019], https://www.everycrsreport.com/reports/R45039.html 
Cummings, M.L. (2019). Crowdsourcing as a Learning Paradigm: A Model Based on Excess Capacity. U-turn Press.

Downes, S. (2007). E-Learning 2.0 in Development [slides] [online] [30.11.2019], http://www.slideshare.net/Downes/elearning-20-in-development

FCC (2010). Connecting America: The National Broadband Plan [online]. Federal Communications Commission [30.11.2019], https://transition.fcc.gov/national-broadband-plan/national-broadband-plan.pdf

Gartner (2019). Gartner Says 5.8 Billion Enterprise and Automotive IoT Endpoints Will Be in use in 2020 [online]. Gartner. Newsroom. Press Releases [30.11.2019], https://www.gartner.com/en/ newsroom/press-releases/2019-08-29-gartner-says-5-8-billion-enterprise-and-automotive-io

Good, I.J. (1966). Speculations Concerning the First Ultraintelligent Machine. Advances in Computers, 6 (C), 31-88. https://doi.org/10.1016/S0065-2458(08)60418-0

Jackson, K.L., Goessling, S. (2018). Architecting Cloud Computing Solutions: Build Cloud Strategies That Align Technology and Economics While Effectively Managing Risk. Birmingham: Packt Publishing. Jacobfeuerborn, B. (2010). e-learning Platforms Evaluation Dilemmas. Edukacja, 2(110), 75-79.

McCarthy, J. (2007). What is Artificial Intelligence? [online]. John McCarthy's Home Page

[18.10.2019], http://jmc.stanford.edu/articles/whatisai/whatisai.pdf

Montebello, M. (2018). AI Injected e-Learning: The Future of Online Education. Cham: Springer.

MT (2019). Media Tracker [online]. data.gov.uk [27.10.2019], http://data.gov.uk/dataset/0a1edff8-adbe-472c-aa34-6a7ae38230e8/media-tracker

NAMLE (2019). Media Literacy Defined. The Basic Definition [online]. National Association for Media Literacy Education [27.10.2019], https://namle.net/publications/media-literacy-definitions/

Ofcom (2019a). About Media Literacy [online]. Ofcom, May 2019 [27.10.2019], http://www.ofcom. org.uk/research-and-data/media-literacy-research/media-literacy

Ofcom (2019b). Adults: Media Use and Attitudes Report [online] [02.12.2019], https://www.ofcom. org.uk/_data/assets/pdf_file/0021/149124/adults-media-use-and-attitudes-report.pdf

Palloff, R.M., Pratt, K. (2009). Building Online Learning Communities: Effective Strategies for the Virtual Classroom, 2nd ed. San Franciso: Jossey-Bass.

Reich, E., Knight, K,. (1991). Artificial Intelligence. New York: McGraw-Hill.

Robinson, K. (2010, Feb.). Bring on the Learning Revolution! [video file] [online] [16.10.2019], http:// www. ted.com/talks/sir_ken_robinson_bring_on_the_revolution.html

Rosenberg, J. (2010). The Cloud at Your Service: the When, How, and Why of Enterprise Cloud Computing. Greenwich: Manning Publications.

Sosinsky, B. (2011). Cloud Computing Bible. Indianapolis: Wiley Publishing.

Stevenson, C.N., Bauer, J.C., eds. (2019). Enriching Collaboration and Communication in Online Learning Communities. Hershey, PA: IGI Global.

Surowiecki, J. (2005). The Wisdom of Crowds. London: Abacus.

\title{
Synergetyczny wpływ technik sztucznej inteligencji, Internetu Rzeczy i łączności 5G na kompetencje informacyjne i edukację
}

\author{
Abstrakt \\ Cel/Teza: Celem pracy jest zaprezentowanie i pokazanie, że współdziałające z sobą trzy techniki, \\ a mianowicie: sztuczna inteligencja (SI), Internet Rzeczy (IRz) oraz dostęp szerokopasmowy $5 \mathrm{G}$ mogą
}


pozytywnie wpłynąć na procesy budowania kompetencji informacyjnych oraz na edukację. Techniki te bowiem dostarczają nowych metod i narzędzi, które mogą wesprzeć innowacyjność i kreatywność skutkujące opracowaniem lepszych ekosystemów edukacyjnych.

Koncepcja/Metody badań: Pracę oparto na metodzie, która ma dwa składniki, a mianowicie: (i) prezentację i analizę cech technik SI, IRz i 5 G oraz sposobów w jakie mogą one wzajemnie współdziałać w celu budowania nowych modeli i wzorców edukacyjnych, po czym następuje analiza zagadnień kompetencji cyfrowych z rozbiciem na kompetencje dotyczące użycia urządzeń cyfrowych (komputery, smartfony, Internet), kompetencje informacyjne i kompetencje w zakresie mediów, (ii) pokazanie jak techniki SI, IRz oraz 5 G mogą wspierać procesy edukacyjne i budowanie kompetencji cyfrowych. Wyniki i wnioski: Wynikiem pracy jest przebadanie i prezentacja współdziałania ze sobą trzech technik: SI, IRz oraz 5G w celu przekształcania modeli i procesów edukacyjnych. Łącznie te trzy techniki mają duży potencjał na rzecz wspierania procesów uczenia się i nauczania oraz inspirowania prac nad tworzeniem ekosystemów edukacyjnych nowej generacji. Trzeba przy tym podkreślić, że w epoce cyfrowej edukacja jest zbyt ważną sprawą, by zostawić ją wyłącznie nauczycielom i inżynierom technik informacyjnych. Uczniowie, studenci, a także zainteresowane środowiska obywatelskie powinny również brać czynny udział w tworzeniu nowych form i praktyk edukacyjnych.

Oryginalność/Wartość poznawcza: Badanie potwierdziło hipotezę, że współdziałanie z sobą trzech technik - SI, IRz oraz 5G - stanowi wartość dodaną i może znacząco wpłynąć na transformację obecnych modeli i wzorców edukacyjnych, w szczególności na kwestie dotyczące kompetencji informacyjnych, co jest warunkiem koniecznym skuteczności systemu edukacyjnego w epoce cyfrowej. Współdziałanie to może pomóc nauczycielom i uczącym się w wyzwoleniu innowacyjności nakierowanej na rozwój ekosystemów edukacyjnych nowej generacji, co powinno uczynić uczenie się i nauczanie bardziej efektywne oraz znacznie zwiększyć liczbę osób uczących się.

\section{Słowa kluczowe}

Edukacja. Internet Rzeczy. Kompetencje informacyjne. Łączność 5G. Sztuczna inteligencja.

MIECZYSEAW MURASZKIEWICZ is a full professor at the Faculty of Economics and Informatics in Vilnius, Lithuania (Branch of University of Bialystok) and at the Institute of Computer Science at Warsaw University of Technology. His research interests cover intelligent information systems, methods of knowledge representation, the issues of academic education, and the relationships between technology and culture as well as the issues of innovativeness. His recent publications are: S. Grabowski, M. Muraszkiewicz: Modelowanie ekosystemów informacyjnych dla innowacyjnych społeczności programistycznych (Zagadnienia Informacji Naukowej, 2017); M. Muraszkiewicz: An Essay on Information Overload (Zagadnienia Informacji Naukowej, 2014); B. Jacobfeuerborn, M. Muraszkiewicz: Some Challenges and Trends in Information Science. (R. Bembenik et. al. (red.), Intelligent Tools for Building a Scientific Information Platform: From Research to Implementation, Springer, 2014); B. Jacobfeuerborn,M. Muraszkiewicz: Media, Information Overload, and Information Science (R. Bembenik et. al. (red.), Intelligent Tools for Building Scientific Information Platform. Advanced Architectures and Solutions, Springer, 2013).

Contact to the Author:

m.muraszkiewicz@uwb.edu.pl

Uniwersytet $w$ Biatymstoku

Wydziat Ekonomiczno-Informatyczny w Wilnie

Kalvariju g. 135

Lt-08221 Vilnius, Lithuania 